\title{
Manajemen Pendidikan Pondok Pesantren dalam Membentuk Learning Society
}

Aji Muhammad Iqbal', Annisa Mayasari², Asep Supriyadi ${ }^{3}$, Muhibbin Syah ${ }^{4}$, Muhammad Erihadiana ${ }^{5}$

1,2,3,4,5Universitas Islam Negeri Sunan Gunung Djati Bandung, Indonesia

E-mail: ajimuhammaf92@gmail.com, annisamayasari020@gmail.com, asepktr@gmail.com,

muhibbinsyah@yahoo.com

\section{Article Info \\ Article History \\ Received: 2021-11-10 \\ Revised: 2021-11-28}

Published: 2021-12-08

Keywords:

Management;

Boarding school;

Learning Society.

\begin{abstract}
The purpose of this study was to obtain an overview of Islamic Boarding School Education Management in Forming a Learning Society. This research is a qualitative research that seeks an in-depth description of a phenomenon that occurs. The results of the study explain that Islamic boarding schools are educational institutions that are established and managed independently by the community, which in this case we can see the large role of the community in building the character and mental strength of the nation's children, even not only in the field of education, in this case the Zawiyah Islamic Boarding School. has transformed into an institution that builds the economy and absorbs labor with the presence of cooperatives in a boarding school, this makes Islamic boarding schools able to stand independently, the Learning Society planned by Islamic boarding schools has been carried out in stages, it is proven that Islamic boarding schools absorb teaching staff and business unit employees recruit from the community around. However, in terms of developing Islamic boarding schools, the government's presence is very necessary and even obliged to attend so that development in one Islamic boarding school does not run slowly if the government takes part in realizing an independent Islamic boarding school.
\end{abstract}

\begin{tabular}{l}
\hline Artikel Info \\
\hline Sejarah Artikel \\
Diterima: 2021-11-10 \\
Direvisi: 2021-11-28 \\
Dipublikasi: 2021-12-08
\end{tabular}

Kata kunci:

Manajemen;

Pesantren;

Learning Society;

\section{PENDAHULUAN}

Dalam konteks pendidikan sering muncul istilah bahwa pendidikan tidak menyentuh tataran praktis. Pendidikan terkadang dikambing hitamkan karena tidak mampu menjawab tantangan kehidupan. Terjadi pengangguran merupakan salah satu gejala masalah yang muncul akibat pendidikan yang tidak dapat merespon konteks realitas, adanya learning society ini sebagai tawaran diskursus baru yang ada di dunia pendidikan, maka problem utamanya hanya satu; adanya diskoneksitas antara sekolah dan kehidupan nyata di masyarakat. "How can we get people into school?" we need to ask "How can we enable people to learn most effectively throughout their lives?". Kata-kata ini setidaknya bermakna bagaimana kita mengajak orang masuk ke dalam sekolah, sedangkan di dalam sekolah sendiri, tidak menyediakan apa yang dibutuhkan untuk kehidupan panjang (long-life term) para peserta didik. Berawal dari itu, learning society ini hadir, dalam bahasa lain, hingga saat ini, ada masalah utama sistem pendidikan. Yaitu tidak adanya sinergi antara apa yang diajarkan sekolah dan kehidupan sosial. Pertanyaan selanjutnya adalah, 
apakah learning society bisa menjadi solusi ampuh. Jawabannya juga tidak secara otomatis ampuh. Karena pada taraf implementasinya akan mendapatkan problem-problem baru yang akan dihadapi.

Learning society mulai diperkenalkan pada tahun 1971 oleh Torsten Husen. Learning society dimaksudkan sebagai memberdayakan peran masyarakat dan keluarga dalam bidang pendidikan. Learning society secara praktek sudah dilakukan oleh masyarakat Indonesia meski belum secara maksimal- namun secara konsep masih meraba-raba. Artinya, bila civil society telah mulai diperkenalkan dan disosialisasikan, maka untuk learning society belum ditemukan konsep yang matang dan fixed, sehingga istilah learning society belum populer didengungkan apalagi dimasyarakatkan (Nizar, 2005). Pembahasan tentang learning society pada tahun 1971 telah diperkenalkan oleh Husen. Menurut (Husen, 1995), learning society adalah memberdayakan peran masyarakat dan keluarga dalam bidang Pendidikan.

Dari berbagai pendapat di atas dapat ditarik simpulan bahwa masyarakat belajar adalah masyarakat yang secara terus menerus melakukan aktivitas belajar. Learning society merupakan konsep pendidikan yang di samping menjadi tanggung jawab lembaga pendidikan formal, juga menjadi tanggung jawab keluarga dan masyarakat. Di samping memberdayakan pendidikan keluarga, upaya mewujudkan learning society adalah dengan meningkatkan partisipasi masyarakat (Wathoni, 2011), masyarakat bukan hanya menitikberatkan pada bagaimana memulai membaca tetapi lebih pada bagaimana membaca sebanyak mungkin agar selalu mendapatkan informasi terbaru (Sarwoyo, 2010). Jadi masyarakat belajar di sini adalah masyarakat yang selalu belajar, sehingga timbullah kesadaran yang tinggi akan pentingnya belajar tanpa harus digerakkan oleh institusi atau lembaga manapun, karena masalah pendidikan bukan menjadi masalah individu, melainkan menjadi masalah masyarakat secara keseluruhan.

Pendidikan berbasis masyarakat bisa didefinisikan sebagai proses pendidikan di mana individu (dalam hal ini orang dewasa) menjadi lebih kompeten dalam hal keterampilan, sikap, dan konsep, sebagai upaya untuk dapat hidup di dalam masyarakat dan mengontrol aspek-aspek lokal dari masyarakat tersebut lewat pastisipasi demokratis (Hasbi, 2021), masyarakat belajar yang profesional berarti semua warga sekolah selalu berusaha untuk: (1) mengejar dan mengembangkan kepandaian atau keahlian secara terus-menerus sesuai dengan bidang; (2) komitmen terhadap kualitas; (3) memiliki dan mengembangkan rasa tanggung jawab moral, sosial, intelektual dan spiritual; serta (4) memiliki dan mengembangkan rasa kesejawatan dan/atau teamwork yang cerdas, dinamis, dan kompak.

Adapun harapan-harapan yang hendak dicapai dri learning society (masyarakat belajar) antara lain sebagai berikut: Pertama, terciptanya masyarakat yang beriman dan bertaqwa pada Tuhan Yang Maha Esa. Tatanan masyarakat agamis yang bersifat dinamis karena memiliki perspektif moral. Kedua, terciptanya masyarakat yang demokratis dan beradab, yang mau dan mampu menghargai adanya perbedaan pendapat. Ketiga, masyarakat yang mengakui adanya HakHak Asasi Manusia, menjunjung tinggi nilai-nilai HAM itu sendiri. Keempat, masyarakat yang tertib dan sadar hukum, budaya malu untuk melanggar hukum, melekat dalam semua sendi kehidupan kenegaraan dan kemasyarakatan. Kelima, masyarakat yang percaya pada diri sendiri, memiliki kamandirian dan kreatif terhadap pemecahan masalah yang dihadapi, masyarakat memiliki orientasi yang kuat pada penguasaan ilmu dan teknologi. Kemajuan ini akan ditandai dengan tatanan kehidupan yang dinamis, kompetitif, inovatif, memiliki dinamika batiniyah yang kuat untuk meraih kemajuankemajuan demi kepentingan bangsa, berwawasan luas, berorientasi jauh ke depan dan tidak hanya pemakai teknologi atau sasaran permasaran bahan-bahan jadi dari luar negeri, melainkan memberikan kontribusi terhadap terwujudnya suatu masyarakat Indonesia yang maju dalam peradaban ilmu dan teknologi di masa mendatang. Keenam, terwujudnya tatanan masyarakat yang beradab yang menjunjung tinggi nilai-nilai luhur yang telah mengakar dalam tatanan masyarakat Indonesia, yang tercermin dalam: ukhuwah Islamiyah, silaturrahmi, persamaan, adil, baik sengak, rendah hati, tepat janji, lapang dada, dapat dipercaya, harga diri dan sebagainya. Kedelapan, mewujudkan Masyarakat Belajar yang tumbuh dari, oleh, dan untuk masyarakat. Masyarakat Belajar ini menempatkan pendidikan sebagai suatu proses yang berlangsung secara terus menerus sepanjang hayat (Media, 2003).

Penyelenggaraan atau kegiatan pendidikan tidak lagi harus terikat oleh ruang, waktu dan kelembagaan. Proses pendidikan dapat berlangsung di mana dan kapan saja. Oleh karena itu, 
pendidikan berbasis masyarakat merupakan satu alternatif menuju terciptanya Masyarakat Belajar (learning society). Apabila delapan poin di atas terlaksana, maka cita-cita besar bangsa Indonesia, terwujudnya masyarakat belajar, menjadi sebuah keniscayaan. Akan tetapi, terwujudnya delapan poin yang dimaksud tidaklah semudah membalikkan telapak tangan yang kemudian butuh waktu yang relatif cepat. Tentunya, diperlukan usaha-usaha ekstra yang selanjutnya dicarikan batu loncatannya untuk diwujudkan.

(Howen, 2009) menyebut bahwa ada beberapa problem utama pengimplementasian learning society; Pertama, roles of tutor. Kedua, culture and curricula. Jika dilihat secara seksama, proses implementasi learning society memang membutuhkan seorang guru, trainer, mentor, atau tutor yang memiliki pemahaman luas terhadap kehidupan masyarakat. Selain itu juga, dia harus bisa membawa para peserta didik untuk masuk ke dalam dimensi sosial yang sedang diceritakan. Pada kenyataannya, peran para pembelajar sangat jauh dari kata berpengalaman. Mereka masih lebih cenderung memindah (transfering) pengetahuan atau informasi yang dimiliki, dibandingkan melakukan sharing tentang pengalaman masing-masing.

Problem lain, yang juga diungkap oleh (Howen, 2009), berkaitan dengan budaya dan kurikulum yang digunakan untuk para peserta didik. Budaya sekolah yang masih limitatif, berdasarkan space dan teritori tertentu, ditambah lagi, ada kecenderungan sekolah terpisah secara lingkungan dengan masyarakat umum, akan menambah gap pemahaman peserta didik dengan kehidupan nyata. Begitu halnya kurikulum. Bagi sebagian praktisi pendidikan, menurtut Claire, kurikulum yang baik adalah kurikulum yang tertulis dan memiliki batasan evaluatif. Padahal, untuk mengimplementasikan konsep learning society harus ada hidden curriculum, yang harus diindoktrinasi kepada peserta didik.

Learning society menggunakan pendekatan manajemen dalam rangka memaksimalkan proses penyelenggaraannya. Manajemen berasal dari bahasa latin, yaitu berasal dari kata manus yang berarti tangan, dan agere artinya melakukan; digabung menjadi kerta kerja managere, berarti menangani; diterjemahkan ke dalam bahasa inggris, to manage, kata bendanya management (mengatur atau mengelola); manajemen kini diartikan pengelolaan. Menurut arti istilah menurut (Bairizki, 2021), banyak pakar yang mengemukakan beragam definisi: (1) manajemen adalah ilmu dan seni perencanaan, pengorganisasian, penyusunan, pengarahan dan pengawasan sumberdaya untuk mencapai tujuan yang sudah ditetapkan, (2) manajemen yaitu segenap proses penyelenggaraan dalam setiap usaha kerjasama sekelompok manusia untuk mencapai tujuan tertentu, dan (3) sejumlah pakar mengartikan: manajemen adalah pencapaian tujuan yang ditetapkan lebih dulu dengan mempergunakan kegiatan orang lain ditetapkan lebih dahulu.

Manajemen yang pada awalnya diterapkan dalam dunia bisnis, ketika diterapkan dalam dunia pendidikan Islam, apakah sedikitpun tidak menimbulkan masalah? Sebagai ilmu tata kelola, pasti sangat banyak yang bisa dimanfaatkan oleh berbagai aktivitas pengelolaan organisasional (sekelompok orang yang berusaha mencapai tujuan bersama), termasuk oleh organisasi atau lembaga pendidikan Islam dan pondok pesantren. Itu sangat masuk akal. Tetapi apakah seluruhnya "pas"?, untuk menjawab pertanyaan ini layaknya perlu kecermatan. Persoalannya berpangkal pada kenyataan, lembaga pendidian Islam yang serius umumnya, apalagi pondok pesantren, tentu memiliki visi-misi keagamaan disamping mencari relevansi seperti lembaga pendidikan lainnya. Misalnya terkait dengan model manajemen yang dipandang paling ideal, yaitu Total Quality Management (TQM).

Salah satu target utama TQM yaitu memuaskan pelanggan. Prinsip dasar manajemen model ini, pelanggan dan kepentingannya dinomor satukan mengalahkan target-target yang lain. Bila TQM diterapkan sepenuhnya dalam lembaga pendidikan agama seperti pondok pesantren, visi-misi keagamaan pondok pesantren bisa disubordinasikan atau mungkin bila perlu dikorbankan. Salah satu kritik terhadap TQM, yaitu penggunaan istilah "pelanggan" (customer). Istilah ini bercorak komersial yang bila berlebihan dalam lembaga pendidikan Islam dapat mengalahkan visi-misi penddikan agama. Tentunya tidak tepatd iaplikasikan didalamnya.

Sebagian yang lain, termasuk di dalamnya Pat Davies dalam (Irwansyah, 2021), berpendapat berbeda tentang challenges (tantangan) yang akan dihadapi sekolah dalam melaksanakan learning society, sebagai model dan sistem sekolah. Pertama, problem kebijakan yang akan diambil oleh pihak sekolah. Kedua, kerangka interaksi masyarkat dalam proses berpartisipasi di sekolah. Ketiga, peranan guru dan orang tua 
untuk menjaga pemahaman peserta didik. Keempat, persoalan core-sub kebudayaan sekolah. Kelima, problem sosial yang ada di luar sekolah. Keenam, diskoneksitas antara sekolah, lembaga swadaya masyarakat, dan pelaku bisnis.

Dari seluruh problem-problem teoritis dan praktis di atas, hal yang juga urgent dieksplorasi adalah bagaimanakah dengan sistem pendidikan yang ada di Indonesia? Semua orang akan menjawab dengan narasi-logika yang mungkin sama. Yakni, persoalan pendidikan di Indonesia sangat kompleks. Sebelum membahas problem atau tantangan spesifik, jika learning society ini diimplementasikan, ada baiknya pula menerangkan beberapa problem pendidikan di Indonesia secara umum, Pertama, problem politik pendidikan nasional. Secara garis besar, problem politik pendidikan di Indonesia selalu berubah-ubah dan tidak konsisten dalam proses implementasinya. Contoh paling sederhana yang bisa terlihat. Di saat diskursus tentang Manajemen Berbasis Sekolah (School Based Managemen) hadir ke Indonesia, kebijakan nasional pendidikan Indonesia berubah dari proses centralistik mengarah pada desentralistik. Tapi, kenyataan di lapangan, banyak lembaga pendidikan, khususnya public school, masih bergantung kepada kebijakan-kebijakan pemerintah, sumber daya manusia yang di-supply oleh pemerintah, termasuk di dalamnya terkait dengan pendanaan. Tidak ada kemandirian murni, sebagaimana amanat konsep School Based Management, Kedua, kurikulum pendidikan nasional yang tidak ada ujung pangkalnya, hingga hari ini. Penyesuaian dan penginovasian kurikulum ke arah yang relevan dengan tuntutan zaman memang sebuah keniscayaan. Namun, bukan berarti harus dirubah sesuai keinginankeinginan politik pemangku kebijakan nasional, Ketiga, profesionalisme guru. Program sertifikasi guru, yang berarti menandakan bahwa akan ada peningkatan kesejahteraan dan guru akan lebih profesional, adalah core-policy agar guru bisa lebih fokus dan concern terhadap murid atau peserta didik. Pada kenyataan di lapangan, orientasi guru mengikuti sertifikasi hanya terfokus pada kesejahteraan semata, tidak sama sekali mementingkan aspek profesionalisme, Keempat, dan paling urgen dalam pandangan penulis, pendidikan nasional Indonesia kehilangan identitas, baik dari sisi makna filosofis dan sosiologis. Artinya, mulai era reformasi hingga saat ini, rancangan pembangunan manusia yang diinginkan Indonesia masih bersifat utopis. Dulu, ada penggalangan kembali "Pendidikan Karakter" sebagai manifestasi kebudayaan indigious Indonesia. Tapi, disaat proses implementasinya, pendidikan karakter yang digadanggadang tersebut berasal dari Congress Character Education di negaranegara maju. Bukan asli budaya Indonesia. Belum lama dilaksanakan, dan masih dalam taraf diskursus, ada keinginan "merevolusi mental", sebuah kata yang lebih mendalam dibandingkan karakter. Kenyataannya, tidak juga terlaksana dengan baik. Problem-problem di atas, adalah common issues yang disadari oleh para pengamat, praktisi, dan akademisi, yang concern menilai pendidikan Indonesia.

Adapun beberapa problem atau tantangan yang akan menjadi hambatan, jika ada keinginan implementasi learning society ini sebagai model pendekatan pendidikan, adalah sebagaimana berikut: 1) Belum adanya koniktifitas yang intensif antara lembaga pendidikan, masyarakat, investor, dan institusi lainnya yang memiliki pengaruh terhadap penyerapan peserta didik pasca keluar dari dunia pendidikan, 2) Belum adanyan konsep masyarakat ideal yang menjadi konsensus bersama. Kata-kata civil society mungkin dianggap konsep ideal. Tapi, secara perwujudannya, masih ada dalam tataran diskursus semata, 3) Belum adanya Sumber Daya Manusia (baca; dari sisi Tutor), yang memahami konsep learning society ini secara baik, 4) Belum adanya kurikulum rujukan yang bagus pula. Sebuah kurikulum yang lebih mengedepankan aspek life-long learning, dan 5) Belum adanya kebijakan-kebijakan makro yang mewajibkan peningkatan kerjasama secara kolektif dari seluruh stake-holder pendidikan. Dari semua problem umum dan spesifik di atas, mustahil kiranya mengimplemenatasikan learning society sebagai model pendidikan di Indonesia. Meskipun harus juga dipahami, bahwa persoalanpersoalan tersebut hadir dengan tanpa solusi. Pada bagian selanjutnya akan membahas salah satu pendekatan untuk bisa keluar dari persoalan tersebut.

Pesantren merupakan lembaga pendidikan yang sudah mengakar kuat di Indonesia. pesantren merupakan lembaga pendidikan yang berpengaruh dalam perkembangan dunia pendidikan di Indonesia. Keberadaanya sudah diakui secara legal formal dengan adanya undang-undang pesantren. Salah satu pesantren yang turut dalam mencerdaskan bangsa adalah pesantren zawiyah di Garut, berdasarkan latar belakang diatas perlu adanya penelitian tentang Manajerial pondok pesantren zawiyah dalam 
membentuk learning societ, mengetahui faktor pendukung dan penghambat manajerial pondok pesantren zawiyah dalam membentuk learning society.

\section{METODE PENELITIAN}

Penelitian ini menggunakan pendekatan kualitatif, tujuan dalam penelitian adalah untuk mendapatkan gambaran Manajemen Pendidikan Pondok Pesantren Dalam Membentuk Learning Society. Menurut (Rahayu, 2020) mengemukakan bahwa penelitian kualitatif merupakan penelitian yang mencari gambaran secara mendalam terkait sebuah fenomena yang terjadi.

A. Jenis Penelitian

Desain kualitatif dipilih dikarenakan penelitian ini lebih cocok menggunakan desain tersebut. Desain ini akan menghasilkan temuan-temuan data deskriptif sebagaimana diungkap oleh Bogdan dan Taylor dalam (Bahri, 2021) mendefinisikan bahwa metode kualitatif itu sebagai prosedur penelitian yang menghasilakan data deskriptif berupa katakata tertulis atau lisan dari orang-orang dan perilaku yang diamati, sedangkan menurut Kirk dan Milter dalam (Arifudin, 2020) mendefinisikan bahwa penelitian kualitatif adalah tradisi tertentu dalam ilmu pengetahuan sosial yang secara fundamental bergantung pada pengamatan manusia dalam kawasanya sendiri dan berhubungan dengan orang-orang tersebut dalam bahasanya dan dalam peristilahanya.

B. Definisi Operasional Objek penelitian

Objek penelitian menurut Idrus dalam (Hadiansah, 2021) dimaknai sebagai yang terkena aktifitas yang dilakukan oleh subjek peneliti. Objek dalam konsep penelitian merujuk pada masalah atau tema yang sedang diteliti. Adapun definisi operasional objek penelitian yaitu manajemen pendidikan pondok pesantren Zawiyah dalam membangun learning society.

C. Subjek Penelitian

Subjek penelitian, menurut Amirin yang dikutip oleh (Sofyan, 2020), merupakan seseorang atau sesuatu yang mengenainya ingin diperoleh keterangan, sedangkan (Arikuntoro, 2006) memberi batasan subjek penelitian sebagai benda, hal atau orang tempat data untuk variable penelitian melekat, dan yang dipermasalahkan, sehingga dari keterangan di atas dapat disimpulkan bahwa Subjek dalam penelitian adalah indiv$\mathrm{idu}$, benda atau organisme yang dijadikan sumber informasi yang dibutuhkan dalam data penelitian. Penelitian ini berlokasi di pondok Pesantren Zawiyah Kecamatan Samarang Garut.

Dalam penelitian kualitatif, Muhajir yang dikutif (Hanafiah, 2021) bahwa pemilihan subjek penelitian dapat menggunakan criterion-based selection, yang didasarkan pada asumsi bahwa subjek tersebut sebagai aktor dalam tema penelitian. Selain criterionbased selection, pemilihan subjek penelitian dapat menggunakan model snow ball. Model snow ball digunakan dalam memperluas subjek penelitian, dalam penelitian ini, digunakan kedua model diatas. Pada tahap awal, peneliti menentukan dan menjumpai informan yang secara struktur memilki kemampuan untuk menjelaskan manajemen pendidikan pondok pesanten Zawiyah Garut dalam membangun learning society. Dengan demikian, diawal penelitian, peneliti menggunakan model criterion-based selection, menurut (Mayasari, 2021) bahwa model criterionbased selection merupakan model penentuan informan yang memenuhi kriteria tertentu. Adapun kriteria informan awal penelitian adalah pengurus Pondok Pesantren Zawiyah yaitu Pengasuh Pondok Pesantren. Informasi yang didapatkan dari Pengasuh Pondok Pesantren menjadi data awal untuk menentukan informan lain yang masih dalam kategori Pengasuh atau pengurus pondok Pesantren, adapun subjek pada penelitian ini adalah Pengurus Pondok Pesantren Zawiyah.

D. Metode Pengumpulan Data

Untuk dapat membuat sebuah kesimpulan, diperlukan serangkaian data yang mendukung. Tentu saja ini membutuhkan sebuah proses pengumpulan data dari subjek yang tepat. Pada penelitian ini peneliti akan mempergunakan teknik wawancara, observasi sebagai teknik pendukungnya dilakukan juga teknik dokumentasi.

\section{E. Analisis Data}

Dalam penelitian ini, peneliti menggunakan model interaktif yang terdiri dari tiga hal utama yaitu reduksi data, penyajian data, dan penarikan data/verivikasi sebagai sesuatu yang jalin menjalin pada saat sebelum, selama, dan sesudah pengumpulan data dalam bentuk yang sejajar, untuk membangun wawasan umum yang disebut analisis.

1) Tahap pengumpulan Data

Dalam proses ini peneliti mengumpulkan berbagai data yang berkaitan dengan 
manajemen pendidikan di Pondok Pesantren Zawiyah. Data-data tersbut dapat diperoleh dari wawancara, observasi dan dokumen. Setelah peneliti mendapatkan gambaran umum manajemen pendidikan di pesantren Zawiyah, barulah peneliti melakukan tahap selanjutnya yaitu tahap reduksi data

2) Tahap reduksi data

Reduksi data dapat diartikan sebagai proses pemilihan, pemusatan perhatian pada penyederhanaan, pengabstrakan, dan transfornasi data kasar yang muncul dari catatan-catatan tertulis dari lapangan. Reduksi data berlangsung secara terus menerus sejalan pelaksanaan penelitian berlangsung. Reduksi data tidak dilakukan hingga menunggu penelitian selesai. Proses ini digunakan oleh peneliti guna menajamkan pertanyaan berlanjut dengan data kasar yang sudah diperoleh pada pengumpulan data awal.

3) Display Data

Langkah display data dimaknai sebagai pengumpulan data informasi tersusun yang memberi kemungkinan adanya penarikan kesimpulan dan pengambilan tindakan. Kegiatan reduksi data dan proses penyajian data adalah aktivitasaktivitas yang terkait langsung dengan proses analisis data model interaktif. Dengan begitu, perlu ditegaskan lagi bahwa proses ini pun berlangsung selama proses penelitian sehingga data lengkap.

4) Verifikasi dan Penarikan Kesimpulan Tahapan ini dilakukan untuk menyimpulkan sesuai dengan intrepertasi dari peneliti. Dalam kegiatan penelitian ini, kesimpulan didapatkan setelahnya menemukan sebuah informasi atau pun data dilapanagan. Namun demikian, kesimpulan itu bukan kesimpulan akhir apabila data yang didapatkan masih kurang mendalam dan kurang fokus. Kesimpulan final baru diperoleh setelahnya selesai proses akhir penelitian.

\section{HASIL DAN PEMBAHASAN}

Berdasarkan hasil dari penelitian yang dilakukan, didapatkan informasi bahwa:

A. Deskripsi Data Penelitian

Percepatan perkembangan ilmu pengetahuan dan teknologi menunjukan pengaruh yang sangat signifikan. Fenomena ini, baik langsung maupun tidak langsung sangat mempengaruhi pola hidup global kemanusiaan. Pola hidup hedonistik, materi-allistik, liberalistik, konsumeristik semakin menyebar merata hampir menyelimuti seluruh lapisan masyarakat, disisi lain terutama dikaitkan dengan Bangsa Indonesia yang sedang dilanda krisis multi dimensi. Dalam bidang ekonomi misalnya, lapangan kerja yang sulit, daya beli rendah, sehingga menimbulkan kemiskinan. Demikian juga dalam bidang pendidikan, selain biayanya tidak terjangkau oleh kebanyakan mansyarakat hasilnya pun tidak menjanjikan, hak untuk mendapatkan pendidikan belum merata sehingga menimbulkan kebodohan. Dalam pada itu pesan-pesan moral agama semakin menjauh dan tidak diindahkan. Hal ini semakin mengantarkan bangsa ini pada krisis yang lebih mendasar yakni ketidak jelasan arah dalam kehidupan. Dan ini merupakan bencana kemanusiaan yang secara fitri dimuliakan Allah swt.

Untuk membangun derajat kemanusiaan yang ada pada diri setiap insan diperlukan upaya konsepsional sebagai pengarah dari pola hidup yang serba kebendaan tersebut menjadi pola hidup seimbang dan berimbang antara kepentingan material (fiddunya hasanah) dan kepentingan spiritual (wafilakhirati hasanah). Pada dataran inilah sistem nilai Islam, sebagai ajaran yang menjunjung tinggi derajat kemanusiaan menjadi sangat penting. Islam sebagai agama hendaklah dipahamai bukan hanya sebagai institusi belaka akan tetapi justru yang dipentingkan adalah sebagai seperangkat nilai-nilai praktis yang berkaitan dengan kebendaaan materiallisme dan kerohanian spiritualisme.

Pada tahap awal Pesantren Al-Zawiyah mengembangkan "Majlis Dzikir dan Do`a", sebagai kelanjutan pengembangan Majlis Dzikir yang di rintis oleh seorang ulama Kharismatik K.H Badruzzaman (1900 - 1969 M.). Hal ini dilakukan melalui pengembangkan pola dakwah pengamalan syariat islam secara praktis melalui pendekatan amalan istighfar, shalawat, dan dzikir. Amalan istighfar dimaksudkan untuk penyadaran hakikat kemanusiaan, amalan salawat kepada Nabi dimaksudkan untuk menanamkan idola ruhani sehingga tertanam aturan dan pola hidup dalam diri, sedang amalan dzikir dimaksudkan untuk membangun sandaran yang kokoh terhadap Dzat Yang Maha mengatur alam dan seluruh kehidupan, 
sebagai modal membangun sikap optimis dalam menghadapi berbagai tantangan kehidupan.

Pada tahapan ini dalam usianya yang baru memasuki satu pelita, pesantren al-Zawiyah telah melakukan upaya kongkrit pembinaan masyarakat secara langsung melalui amalan wirid tersebut. Sampai sekarang telah tersebar jama`ah hampir di setiap kecamatan di kabupaten Garut. Melalui kegiatan "ijtima dzikir dan do'a” yang dilaksanakan satu kali setiap minggu yakni pada setiap hari jum `at sore hari, tidak kurang dari 30.000 jama`ah melakukan amalan wirid dimaksud.

Memasuki usianya yang ke 10 tahun, pesantren Al-Zawiyah mulai memasuki fase barunya, yaitu fase memasuki programprogram pengembangan Sumber Daya Manusia yang sangat terkait dengan tuntutan zaman dengan tanpa menghilangkan akar tradisi awalnya sebagai pesantren yang berperan utama sebagai pusat pengembangan dzikir dan do'a, peran pendidikan merupakan peran yang sangat penting, karena pesantren itu sendiri pada dasarnya adalah lembaga yang mempunyai missi utama di bidang peningkatan kualitas Sumber Daya Manusia, berupa pencerdasan masyarakat dan arti kehidupan yang di alaminya. Sejak awalnya kehadiran, pesantren memang mempunyai tugas penting dalam tanggung jawab mencerdaskan masyarakat tentang berbagai aspek kehidupannya yang mencakup eksistensi manusia, hidup dan kehidupan, sosial kemasyarakatan, ekonomi, politik, budaya, dan lainnya. Yang terpenting dari seluruh misinya itu adalah misi mencerdaskan masyarakat dalam memahami agama serta pengamalannya.

Sebagai upaya meningkatkan kualitas kehidupan masyarakat, Pesantren AlZawiyah terus mengembangkan programprogram yang relevan dengan setiap dinamika kemajuan budaya masyarakat. Oleh karena itu, Pesantren Al-Zawiyah ini bermaksud membangun program pengembangan kualitas Sumber Daya Manusia melalui program pendidikan terpadu pesantren dan sekolah. Untuk keperluan ini, program-program pengembangan itu, disusun berdasarkan prioritas jangkauan waktu, kebutuhan, serta kemampuannya.

Dalam hal Pengembangan dunia pendidikan sejatinya suatu lembaga bersinergi dengan pemerintah, dalam hal ini pondok pesantren zawiyah mewujudkannya dengan membentuk lembaga pendidikan formal SMP yang dinamakan SMP IT SYIS Badruzzaman yang didirikan tahun 2012, SMK SYIS Badruzzaman 2013 dan STAI KH. Badruzzaman 2019, murid yang kita rekrut adalah dari masayarakat sekitar dan alumnialumni pondok pesantren, sehingga mudah dalam hal perekrutan, begitu pula sesuai dengan komitmen pondok pesantren dalam hal membantu pemerintah dalam mengurangi pengangguran, kita melibatkan alumni dan masayarakat sekitar untuk ikut andil dalam hal perekrutan guru dan pengelolaan lembaga tersebut.

Untuk memenuhi semua kegiatan pendidikan yang dilaksanakan di pondok pesantren dan mewujudkan pondok pesantren yang maju secara ekonomi dan berdaulat secara politikpondok pesantren baru masuk ke tahap penguatan ekonomi yakni dengan membuat sumber-sumber penghasilan seperti mendirikan koperasi yang dikelola secara profesional, kemudian membentuk unit usaha koperasi seperti peternakan yang konsentrasi kepada ayam petelur, budidaya jamur serta membuaty pabrik roti dan kopi yang semua unit usaha tersebut dikolola oleh para santri dan masyarakat sekitar, yang dalam perjalannna kadang mengalami kemajuan dan dan kemunduran, namun dari mulai berdiri sampai sekarng unit-unit usaha yang dikelola tersebut memberikan kontribusi yang positif baik dalam pembangunan pesantren dan membantu ekonomi masayarakat sekitar Kepengurusan Koperasi Zawiyah Perkasa Pisan

B. Analisis Hasil Penelitian

Pondok Pesantren Zawiyah dalam melakukan manajemen pengembangannya untuk mewujudkan Learning Society, selalu melibatkan masyarakat sekitar dilihat dari adanya masayarakat yang menjadi pengajar, pegawai di unit-unit usaha yang dimiliki pondok pesantren, sehingga banyak dari masyarakat sekitar yang mendapatkan keberkahan dari berdirinya pondok pesantren dan berimplikasi terhadap majunya unit-unit usaha pondok pesantren, jika dilihat dari faktor penduikung dan penghambatnya dalam perkembangannya, kami dapat menganalisis sebagai berikut: 
1) Kekuatan

Pondok pesantren zawiyah dalam mengembangkan pesantren bukan hanya mengandalkan dari hasil unit usaha pesantren saja namun pondok pesantren zawiyah dikenal dengan jamaahnya yang banyak dan pondok pesantren yang terbuka sehingga pondok ini mampu bersinergi dengan pemerintah, sehingga akses ke pemerintah yang dimiliki dimaksimalkan dengan baik

2) Kelemahan

Pengelolaan yang ada di pondok pesantren masih menggunakan pengelolaan konvensional sehingga dalam mengembangkan unit usaha kadang mengalami kerugian yang mengakibatkan rencana pengembangan tidak terealisasi.

3) Peluang

Dengan jumlah jama'ah yang banyak dan mempunyai jaringan sampai ke daerah pondok ini mempunyai peluang bisa mengambangkan unit usahanya yang nantinya hasilnya bisa digunakan untuk pengembangan pondok pesantren.

4) Tantangan

Kemajuan dunia teknologi yang semakin hari semakin pesat mengharuskan pondok pesantren ini harus terus berupaya agar bisa.

\section{SIMPULAN DAN SARAN}

\section{A. Simpulan}

Pondok pesantren merupakan lembaga pendidikan yang didirikan dan dikelola secara mandiri oleh masyarakat yang dalam hal ini dapat kita lihat begitu besarnya peran serta masyarakat dalam membangun kekuatan karakter dan mental anak bangsa bahkan bukan hanya dibidang pendidikan saja, dalam hal ini Pondok Pesantren Zawiyah sudah bertransformasi menjadi lembaga yang membangun ekonomi dan menyerap tenaga kerja dengan hadirnya koperasi disebuah pesantren ini menjadikan pondok pesantren dapat berdiri secara mandiri, Learning Society yang direncankan oleh ondok pesantren sudah dilakukan secara bertahap, terbukti pondok pesantrten menyerap tenaga pengajar dan karyawan unit usahanya merekrut dari masayarakat sekitar, namun dalam hal pengembangan pondok pesantrenpun tak lepas dari wajibnya kehadiran pemerintah sangat diperlukan dan bahkan wajib hadir pula agar pengembangan dalam satu pondok pesantren tidak berjalan lambat jika pemerintah ikut andil dalam mewujudkan pondok pesantren yang mandiri.

\section{B. Saran}

Pondok pesantren tradisional yang merupakan ciri khas dari pondok pesantren yang ada di indonesia ini jika ingin terus berkembang harus terus berupaya bertransformasi mengikuti arah gerakan teknologi dan pembangunan, serta dalam mewujudkannya pemerintah pula harus bisa dan wajib bersinergi dengan pondok pesantren agar semua program yang dicanangkan oleh pemerintah berjalan dan beriringan dengan majunya lembaga-lembaga pendidikan khusus nya pesantren.

\section{DAFTAR RUJUKAN}

Arifudin, 0. (2020). Pengaruh Penempatan Karyawan Terhadap Efektivitas Kerja Pada PT Agro Bumi. Value : Jurnal Manajemen Dan Akuntansi, 15(2), 14-21.

Bahri, A. S. (2021). Pengantar Penelitian Pendidikan (Sebuah Tinjauan Teori dan Praktis). Bandung : Widina Bhakti Persada.

Bairizki, A. (2021). Manajemen Perubahan. Bandung : Widina Bhakti Persada.

Hadiansah, D. (2021). Membaca Perspektif Balanced Scorecard. Bandung: Azka Hafidz Maulana Foundation.

Hanafiah. (2021). Pelatihan Software Mendeley Dalam Peningkatan Kualitas Artikel Ilmiah Bagi Mahasiswa. Jurnal Karya Abdi Masyarakat, 5(2), 213-220.

Hasbi, I. (2021). Administrasi Pendidikan (Tinjauan Teori Dan Praktik). Bandung: Widina Bhakti Persada.

Howen, C. (2009). Foundation of Learning Society Based Problems and Solving. Hononalu: Blackwell Pub.

Husen, T. (1995). Masyarakat Belajar, terjemahan Surono Hargsewoyo. Jakarta: Raja Grafindo Persada.

Irwansyah, R. (2021). Perkembangan Peserta Didik. Bandung : Widina Bhakti Persada.

Mayasari, A. (2021). Implementasi Sistem Informasi Manajemen Akademik Berbasis 
Teknologi Informasi dalam Meningkatkan Mutu Pelayanan Pembelajaran di SMK. JIIPJurnal Ilmiah Ilmu Pendidikan, 4(5), 340345. https://doi.org/10.54371/jiip.v4i5.277

Rahayu, Y. N. (2020). Program Linier (Teori Dan Aplikasi). Bandung: Widina Bhakti Persada.

Sarwoyo, V. (2010). Mewujudkan Learning Society Melalui Optimalisasi Fungsi dan Peran Perpustakaan. Jurnal Kependidikan Dan Kemasyarakatan, 7(2), 66-72.
Sofyan, Y. (2020). Peranan Konseling Dosen Wali Dalam Meningkatkan Motivasi Belajar Mahasiswa Di Perguruan Tinggi Swasta Wilayah LLDIKTI IV. Jurnal Bimbingan Dan Konseling Islam, 10(2), 237-242.

Media, T. P. (2003). Undang-undang RI No. 20 Tahun 2003 Sistem Pendidikan Nasional. Bandung: Fokusmedia.

Wathoni. (2011). Peran Masyarakat Dalam Membentuk Learning Society. Jurnal Kependidikan Dan Kemasyarakatan, 9(2), 225-231. 